\title{
Newcastle disease virus, rituximab, and doxorubicin combination as anti-hematological malignancy therapy
}

This article was published in the following Dove Press journal:

Oncolytic Virotherapy

20 April 2016

Number of times this article has been viewed

\begin{abstract}
Ahmed Majeed
Al-Shammari'

Huda Rameez ${ }^{2}$

Maha F Al-Taee ${ }^{2}$

'Department of Experimental Therapy, Iraqi Center for Cancer and Medical Genetic Research, Mustansiriyah University, ${ }^{2}$ Department of Biotechnology, College of Science, Baghdad University, Baghdad, Iraq
\end{abstract}

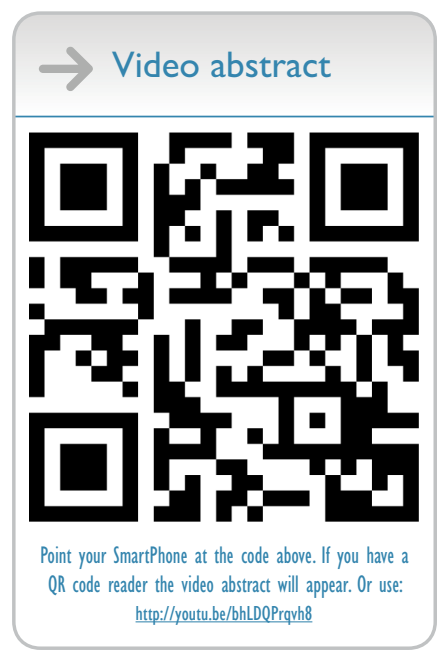

Correspondence:Ahmed Majeed Al-Shammari

Department of Experimental Therapy, Iraqi Center for Cancer and Medical Genetic Research, Mustansiriyah University, PO Box I5007, Al-Yarmook post office, Baghdad, Iraq Email Ahmed.alshammari@iccmgr.org

\begin{abstract}
Hematological malignancies are important diseases that need more powerful therapeutics. Even with current targeting therapies, such as rituximab and other chemotherapeutic agents, there is a need to develop new treatment strategies. Combination therapy seems the best option to target the tumor cells by different mechanisms. Virotherapy is a very promising treatment modality, as it is selective, safe, and causes cancer destruction. The Iraqi strain of Newcastle disease virus (NDV) has proved to be effective both in vitro and in vivo. In the current work, we tested its ability on anti-hematological tumors and enhanced current treatments with combination therapy, and studied this combination using Chou-Talalay analysis. p53 concentration was measured to evaluate the mechanism of this proposed synergism. The results showed that NDV was synergistic with doxorubicin in low doses on plasmacytoma cells, with no involvement of p53 pathways, but involved p53 when the combination was used on nonHodgkin lymphoma cells. NDV in combination with rituximab showed enhanced cytotoxicity that was p53-independent. In conclusion, this work proposes a novel combination modality for treatment of some hematological malignancies.
\end{abstract}

Keywords: oncolytic viruses, virotherapy, combination therapy

\section{Introduction}

Hematological malignancies are a collection of heterogeneous conditions that originate in bone marrow cells and the lymphatic system. There are three groups - leukemia, lymphoma, and plasma-cell neoplasms - and their overall incidence is rising. ${ }^{1}$ Malignancies are still the leading cause of death, despite advances in surgery, chemotherapy, and radiotherapy. This has led to the development of new treatment strategies, such as virotherapy. ${ }^{2}$ Virotherapy has become a promising option, as the viral replication provides continuous amplification of the injected dose, which continues until stopped by the immune response, and it enters and destroys cancer cells without affecting surrounding normal cells. It is also safe, with minimal side effects, as well as genetically stable. ${ }^{3,4}$

The avian Newcastle disease virus (NDV) is a naturally oncotropic RNA virus. ${ }^{5}$ The virulent Iraqi ND strain of avian paramyxovirus of the Avulavirus genus belongs to the family Paramyxoviridae. ${ }^{6} \mathrm{NDV}$ is a promising antitumor agent that replicates rapidly and infects neighboring tumor cells through the release of progeny virions. ${ }^{7}$ NDV kills tumor cells by other mechanisms, such as modification of the tumor-cell surface and generation of specific cellular immune responses. ${ }^{8,9}$ Moreover, NDV can kill tumor cells through induction of apoptosis in the infected cells. ${ }^{10-12}$ NDV replication is independent of the host-cell DNA replication that is the target of most

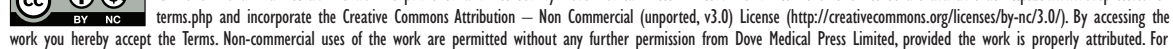
permission for commercial use of this work, please see paragraphs 4.2 and 5 of our Terms (https://www.dovepress.com/terms.php). 
chemotherapeutic drugs as well as radiotherapy, and that makes NDV a candidate oncolytic agent to break resistance of tumor cells to the therapies. ${ }^{5}$ The Iraqi NDV strain has shown a broad antitumor spectrum, and in this study we tested its therapeutic effect on hematological tumors alone or in combination with other therapies.

Oncolytic virotherapy alone has not been fully effective in the eradication of the tumors in either animal models or clinical studies. The best chance for complete tumor destruction is by combining its mechanism of action with other treatment strategies of chemo- and radiation therapies and the emerging field of gene therapy. ${ }^{13}$ Combination strategies attack tumor cells through different mechanisms of action to prevent tumor cells from having time to develop resistance to treatment. ${ }^{14,15}$ Combination of chemotherapy with virotherapy is a promising treatment for cancer. ${ }^{16}$ Despite the fact that it is alluring to combine an oncolytic virus directly with the existing standard chemotherapeutic agents, the final goal of such therapies is to have a potentially synergistic combination strategy that can be easily and safely applied in the clinic. ${ }^{17}$

Rituximab (Rtx), the humanized chimeric anti-CD20 monoclonal antibody, can treat B-cell malignancies and low-grade or follicular non-Hodgkin lymphoma. ${ }^{18}$ It can induce killing of $\mathrm{CD} 20^{+}$cells via direct and indirect effects. Direct effects include complement-mediated cytotoxicity and antibody-dependent cell-mediated cytotoxicity. Indirect effects include structural changes, apoptosis, and sensitization of cancer cells to chemotherapy. ${ }^{19,20}$ Rtx is very often given in combination with chemotherapeutic agents, as it leads to enhanced success rates. ${ }^{21}$ This new antitumor agent was chosen in our study because it is targeting CD20+ on hematological tumors. Also, doxorubicin (Dox) is an anticancer agent with a wide range of good activity against tumors, and was used for the current study to expand the antitumor effect to include CD20- hematological tumors. Its mode of action is a topoisomerase II poison; it also exhibits a number of other cellular responses, such as the ability to form adducts with DNA. ${ }^{22}$ Oncolytic virotherapy is able to augment the antineoplastic mechanism of chemotherapy. ${ }^{23}$ We have previously proved the ability of the Iraqi NDV strain to enhance the antitumor activity of mitomycin $\mathrm{C}$ and act in synergism with cyclophosphamide against different types of tumor-cell lines. $^{24}$

Inactivation of the p53 tumor-suppressor protein is a recurrent event during tumorigenesis. The p53 gene is mutated very often, giving rise to a stable mutant protein that not only loses its tumor-suppressive activities but frequently has extra oncogenic functions that provide cells with growth and survival advantages. ${ }^{25}$ Measuring $\mathrm{p} 53$ response may give an indication of the suggested synergistic mechanisms. Lane et $\mathrm{al}^{26}$ reported that understanding of the $\mathrm{p} 53$ response in cancer cells allowed the development of enhanced drug combinations that may increase chemotherapy selectivity and safety. p53 is a powerful tumor suppressor and an attractive cancer-therapy target. A breakthrough in anticancer research was the discovery of the therapies that are capable of reactivating p53 function. The majority of the anti-hematological malignancy agents, from traditional chemo- and radiation therapies to more recently developed small molecules, deploy their effects by intensifying the antiproliferative activities of $\mathrm{p} 53 .{ }^{27}$

The aim of this work was to establish an anti-hematological malignancy combination therapy by using NDV in CD $20^{+}$ and $\mathrm{CD} 20^{-}$hematological malignancy cell lines: the CD20 ${ }^{+}$ plasmacytoma cell line used Rtx, and the CD20- lymphoma cell line used Dox.

\section{Materials and methods Cells and cell culture}

This study was approved by the Iraqi Center for Cancer and Medical Genetic Research ethics board and Baghdad University, College of Science Ethics Committee. The human non-Hodgkin (large cell immunoblastic) lymphoma SR cell line $\left(\mathrm{CD} 20^{-}\right)^{28}$ was obtained from Dr SJ Russell, Mayo Clinic, Molecular Medicine Department (Rochester, MN, USA) and cultured in modified Eagle's media (United States Biological, Salem, MA, USA) with 5\% fetal bovine serum (Capricorn Scientific, Ebsdorfergrund, Germany). The Rat Embryo Fibroblast Cell line (REF), plasmacytoma cell line $^{29}$ and HeLa epithelial carcinoma cell line were obtained from the Department of Experimental Therapy, Iraqi Center for Cancer and Medical Genetic Research (ICCMGR; Baghdad, Iraq). All the cells were cultured in Roswell Park Memorial Institute 1640 medium (United States Biological) with $10 \%$ fetal bovine serum, 100 units $/ \mathrm{mL}$ penicillin, and $100 \mu \mathrm{g} / \mathrm{mL}$ streptomycin (Capricorn Scientific), and incubated at $37^{\circ} \mathrm{C}$.

\section{Virus}

The virulent Iraqi strain of NDV (Iraq/Najaf/ICCMGR/2013) was supplied from ICCMGR (Cell Bank Unit, Department of Experimental Therapeutics). A stock of infectious virus was propagated in embryonated chicken eggs, harvested from allantoic fluid, and purified from debris by centrifugation $\left(3,000 \mathrm{rpm}, 30\right.$ minutes, $\left.4^{\circ} \mathrm{C}\right)$. NDV was quantified by a hemagglutination test in which 1 hemagglutination unit was defined as the smallest virus concentration leading to visible chicken erythrocyte agglutination. Furthermore, the 
virus was quantified using plaque-forming unit test on $\mathrm{HeLa}$ cells according to standard procedure.

\section{Immunocytochemistry}

The plasmacytoma cells were cultured on coverslips. The cells were allowed to develop a monolayer. Then, the cells were fixed with $4 \%$ neutral buffer formalin for 10 minutes, washed with phosphate-buffered saline (PBS), and left to dry. After fixation, slides were incubated in a humidified chamber with $1 \% \mathrm{H}_{2} \mathrm{O}_{2}$ for 10 minutes, washed two to three times with PBS, and incubated with $1.5 \%$ blocking serum for 30-40 minutes at room temperature. Then, the primary antibody of the rabbit anti-CD20 (Santa Cruz Biotechnology Inc., Dallas, TX, USA) was incubated overnight at $4^{\circ} \mathrm{C}$ in a humidified chamber. Afterward, it was stained by the ImmunoCruz ${ }^{\mathrm{TM}}$ mouse $\mathrm{ABC}$ staining system (Santa Cruz Biotechnology). The biotinylated secondary antibody was incubated for 30 minutes, and then washed. Avidin horseradish peroxidase was then added and incubated for another 30 minutes, then washed. Liquid 3,3'diaminobenzidine chromogen-solution formula was added to each slide for 20 minutes at room temperature, washed extensively with PBS, and counterstained with hematoxylin for 30-60 seconds. The slides were mounted with Distyrene, a plasticizer, and xylene (DPX) (supplied by Sigma-Aldrich Co., St Louis, MO, USA), inspected using light microscopy, and photographed using a digital camera.

\section{Combination cytotoxicity assays and Chou-Talalay analysis}

SR, REF, and plasmacytoma cells were seeded at 10,000 cells/ well into 96-well plates and incubated overnight. NDV was added first at a multiplicity of infection (MOI) of 1 with twofold serial dilutions and incubated for 2 hours at room temperature. Then, Rtx or Dox (Sigma-Aldrich Co, St Louis, MO, USA) was added at the indicated concentration $(2.5,1.25$, $0.625,0.3125,0.1562,0.078 \mu \mathrm{g} / \mathrm{mL}$ ) as serial dilutions to test growth inhibition. After 3 days of incubation, cell-viability

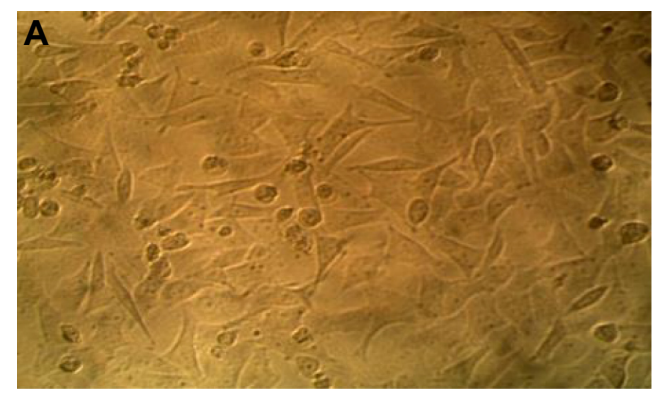

assays were performed to assess the growth-inhibition rate. Cell viability was measured after 72 hours of infection by removing the medium, adding $28 \mu \mathrm{L}$ of a $2 \mathrm{mg} / \mathrm{mL}$ MTT solution, and incubating for 1.5 hours at $37^{\circ} \mathrm{C}$. After removal of the MTT solution, the crystals remaining in the wells were solubilized by the addition of $130 \mu \mathrm{L}$ of dimethyl sulfoxide (Santa Cruz Biotechnology), followed by $37^{\circ} \mathrm{C}$ incubation for 15 minutes with shaking. Absorbance was determined on a microplate reader (Expert Plus reader; Asys Hitech GmbH, Eugendorf, Austria) at $492 \mathrm{~nm}$ (test wavelength); the assay was performed in triplicate.

Median-effect doses $\left(\mathrm{ED}_{50}\right)$ were calculated for the drug and NDV for each cell line. For synergism determination, NDV and drugs were studied as inconstant ratios. To analyze the combination of NDV and chemotherapeutics, Chou-Talalay combination indices (CIs) were calculated using CompuSyn software (ComboSyn Inc., Paramus, NJ, USA). Unfixed ratios of NDV and chemotherapeutics and mutually exclusive equations were used to determine the CIs. A CI between 0.9 and 1.1 is considered additive, whereas CIs $<0.9$ and $>1.1$ indicate synergism and antagonism, respectively. ${ }^{30,31}$

\section{Quantification of $p 53$ protein in plasmacytoma and lymphoma cancer cell lines in treated cells}

To assess the role of 553 in apoptosis induced by combination therapy, p53 was evaluated in plasmacytoma and SR cell lines, and the secretion of the $\mathrm{p} 53$ protein was collected at regular intervals - 12, 24, and 36 hours after exposure - to measure the p53 protein release using a p53 enzyme-linked immunosorbent assay (ELISA) kit (RayBio ${ }^{\circledR}$; RayBiotech Inc., Norcross, GA, USA). The standard curve was plotted using Prism software (version 3.0; GraphPad Software Inc., La Jolla, CA, USA).

\section{Results}

The virulent Iraqi NDV strain grew well on HeLa cells (Figure 1). The cells were used to measure the virus titer in

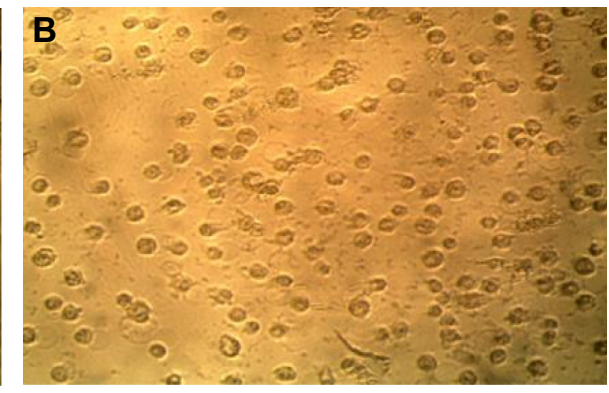

Figure I Showing the cytopathic effect of the NDV on HeLa cells that were used for virus titration $\left(\mathrm{TCID}_{50}\right)$.

Notes: (A) Control HeLa cell line not infected with NDV; (B) HeLa cell line infected with NDV. A cytopathic effect was clearly observed 72 hours after exposure. Magnification: 400x.

Abbreviations: NDV, Newcastle disease virus; TCID, tissue-culture infectious dose. 

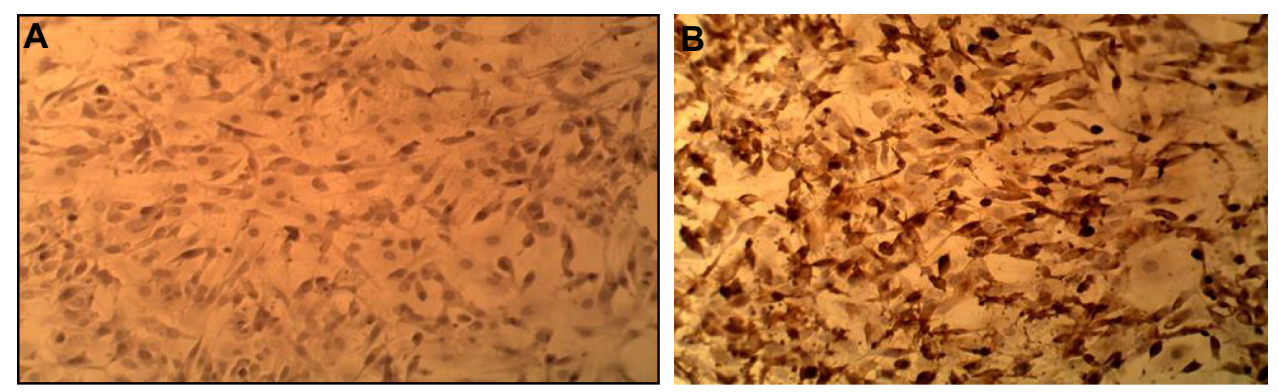

Figure 2 Immunocytochemical study of plasmacytoma cell line (A) and the control (B), showing positive CD20 cells (DAB stain) Magnification: 400X. Abbreviation: DAB, 3,3'-diaminobenzidine.

the allantoic fluids after virus propagation in the embryonated chicken eggs.

\section{Identification of CD20 in plasmacytoma cell line by immunocytochemistry}

Immunocytochemistry results demonstrated that the plasmacytoma cell line was positive for CD20; this test was done to confirm that targeted therapy using Rtx is effective and the targeted antigen is present (Figure 2).

\section{Combination chemotherapy and viral cytotoxicity in vitro}

To study the promising interactions between the virulent Iraqi NDV strain and drugs for the potential therapy of hematological malignancies, the cytotoxicity of NDV in combination with Rtx or Dox was assessed in non-Hodgkin lymphoma (SR) and plasmacytoma cell lines in vitro. A growth-inhibitory effect was seen for the combination of NDV with Dox on both SR and plasmacytoma cells, particularly at low doses. When the combinations of NDV and Dox were tested on normal rat embryo fibroblasts, there seemed to be no favorable interactions at the same low doses; however, at higher doses there was toxicity on the normal cells. The cytotoxic effect of NDV and Rtx was at low and moderate doses, while there was no toxic effect on normal cells at any dose tested.

Potential interactions between NDV and anti-hematological malignancy drugs were evaluated using Chou-Talalay equations. A CI of $<0.9$ is considered synergistic, a CI between 0.9 and 1.1 is considered additive, and a CI of $>1.1$ is considered antagonistic. ${ }^{31}$ For the combination of NDV and Dox, the Chou-Talalay CI was 0.10965 for the plasmacytoma and 0.49082 for the non-Hodgkin lymphoma (SR) cell lines, demonstrating synergistic cytotoxicity (Figure $3 \mathrm{~A}$ and B). Moreover, NDV and Dox had an additive effect at CI 0.49082 on SR cells. The combination of NDV and Dox was antagonistic when tested on embryo fibroblast cells at low doses while it was synergistic at higher doses on the same cells. (Figure 3C).
The combination of NDV and Rtx on the CD20+ plasmacytoma cell line was synergistic (CI 0.005750.000359). As expected, we found that combination ND virotherapy with Rtx was antagonistic and not synergistic at any concentration when tested on rat embryo fibroblast cells (Figure 4).

\section{p53-quantification assay}

We assessed the percentage of $\mathrm{p} 53$ expression in the treated and untreated cells at 12,24, and 36 hours after treatment with NDV, drug and combination, or media only as a control using the quantification ELISA assay for the $\mathrm{p} 53$ protein. For plasmacytoma cells, we tested NDV (MOI 0.06), Dox (0.1562 $\mu \mathrm{g})$, and the NDV + Dox combination. The concentration of p53 for plasmacytoma control, NDV, Dox, and the combination of NDV and Dox was measured (Figure 5A), and showed no significant difference in favor of the combination, while NDV alone showed better $\mathrm{p} 53$ induction. On the other hand, assessment of p53 induction on lymphoma cells showed greatest enhancement. The combination of NDV and Dox showed a significant increase in $\mathrm{p} 53$ expression compared with either NDV or Dox alone at all time intervals tested (Figure 5B).

For the human non-Hodgkin lymphoma cell line (SR) we tested NDV (MOI 0.12), Rtx $(0.3125 \mu \mathrm{g})$, and a combination of these, as it was a synergistic combination. The concentration of p53 for all measured groups showed no significant p53 increase that could have related to the treatment modules (Figure 5C).

\section{Discussion}

The aim of this study was to enhance the hematological malignancy killing effect and overcome resistance to chemotherapy by the combination of virotherapy (using NDV) and recent targeted therapies, such as Rtx, ${ }^{18}$ as well as with chemotherapy widely used for hematological tumors, such as Dox. ${ }^{32}$

Our results showed synergistic cytotoxicity between the virulent Iraqi NDV strain and Dox on plasmacytoma at low 
A

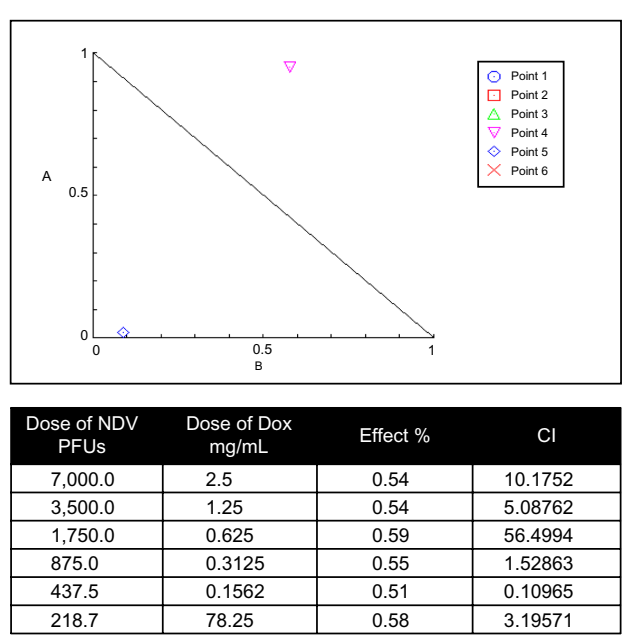

B

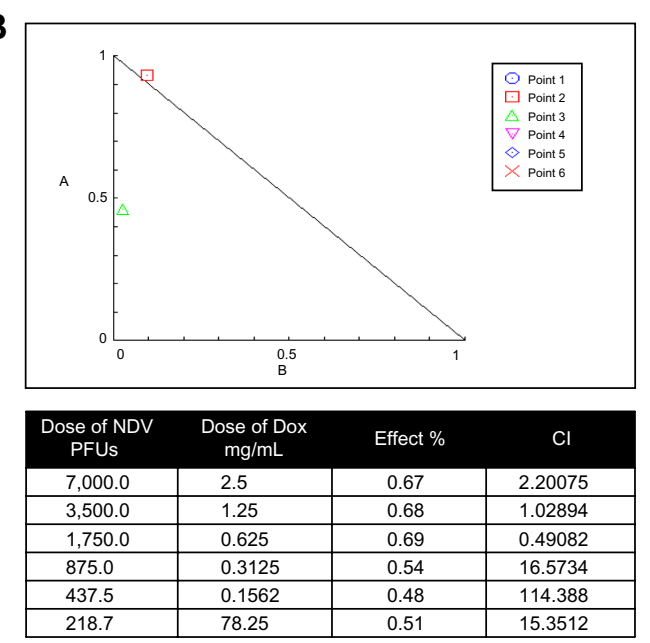

C

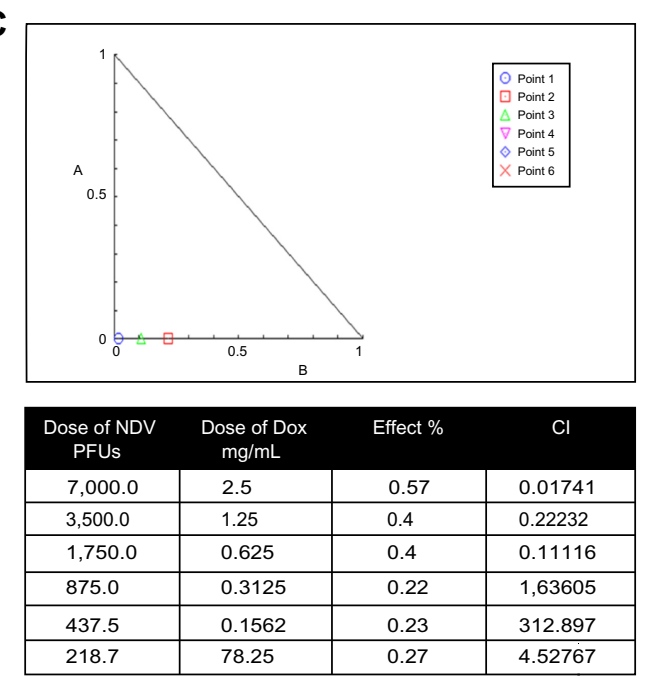

Figure 3 Isobologram analysis of combination NDV oncolytic virus and Dox. Notes: Various viral and drug concentrations were applied alone or in combination for a 3-day exposure period. (A) Effect on plasmacytoma cell line and (B) effect on non-Hodgkin lymphoma (SR) cell line, showing that there was an additive and synergistic combination at low and moderate doses. (C) NDV and Dox was antagonistic when tested on embryo fibroblast cells at low doses while it showed synergism at higher doses.

Abbreviations: NDV, Newcastle disease virus; Dox, doxorubicin; PFUs, plaqueforming units; $\mathrm{Cl}$, combination index. doses. Murine plasmacytoma has been treated with Dox in combination with cisplatin. ${ }^{33}$ The oncolytic paramyxovirus measles virus, which is in the same family as NDV, has been found to be very effective in treating disseminating plasmacytoma. ${ }^{34}$ Moreover, Dox has been used in combination with other treatment modalities to overcome difficulties in treatment of multiple myeloma (plasmacytoma). ${ }^{35}$ The concentration of $\mathrm{p} 53$ for plasmacytoma in the treatment groups showed no significant difference in favor of the combination, while NDV alone showed better p53 induction, which may indicate that synergism was due to other mechanisms.

Dox has a role in the inhibition of DNA synthesis, formation of free radicals, binding and alkylation of DNA, and direct membrane effects; ${ }^{36}$ these are the main mechanisms of action that can synergize with NDV cytolysis or apoptosis inductions. NDV has been found to synergize very well with many chemotherapeutic agents of different modes of action. ${ }^{24}$ NDV and Dox at the synergistic dose was antagonistic when tested on normal embryo fibroblast cells, that showing the safe use of this combination for further future in vivo experimentation. However, there has been one report stating that avian paramyxovirus 1 (a group encompassing NDV) was associated with pneumonia, the authors claiming this incidence as a unique case, most likely an opportunistic infection due to the patient's medical condition, such as immunosuppression owing to HIV infection, chemotherapy for cancer, or organ transplantation. ${ }^{37}$ This report should motivate researchers to find the right combination doses to avoid such conditions.

The results on the human non-Hodgkin lymphoma cell line (SR) showed synergistic cytotoxicity and additive effects between the virulent Iraqi NDV strain and Dox. NDV proved to be able to proliferate and kill lymphoma cells. ${ }^{38}$ Moreover, the p53 experiment for the same synergistic combination showed great enhancement for $\mathrm{p} 53$ induction. The combination of NDV and Dox showed a significant increase in p53 expression compared with either NDV or Dox alone at all time intervals tested, and this result can explain the synergistic cytotoxic and additive action in lymphoma cells, where both NDV and Dox were able to induce p53 expression that led to cell-cycle arrest and apoptosis eventually. In hematological cancers, inducing the p53 pathway will increase treatment efficacy in tumors expressing wild-type $\mathrm{p} 53 .{ }^{39}$ In our experiments, we combined NDV with Dox to enhance killing. Dox can cause early activation of p53 in tumor cells. ${ }^{40}$ Low concentrations of Dox synergize in vitro and in vivo with some other drugs to further enhance p53 activation and to block tumor progression. ${ }^{39}$

The combination of NDV and Rtx on the CD20 plasmacytoma cell line was synergistic. Rtx results in the destruction 
A

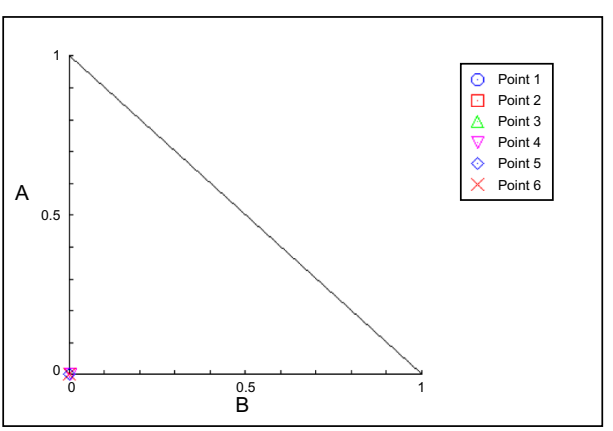

\begin{tabular}{|c|l|c|c|}
$\begin{array}{c}\text { Dose of NDV } \\
\text { PFUs }\end{array}$ & $\begin{array}{c}\text { Dose of Rtx } \\
\boldsymbol{\mu g} / \mathbf{m L}\end{array}$ & \multicolumn{1}{c|}{ Effect \% } & CI \\
\hline $7,000.0$ & 2.5 & 0.49 & 2.78434 \\
\hline $3,500.0$ & 1.25 & 0.46 & 10.8403 \\
\hline $1,750.0$ & 0.625 & 0.69 & 86.6188 \\
\hline 875.0 & 0.3125 & 0.54 & 0.00575 \\
\hline 437.5 & 0.1562 & 0.48 & 0.000359 \\
\hline 218.7 & 78.25 & 0.51 & 0.000361 \\
\hline
\end{tabular}

B

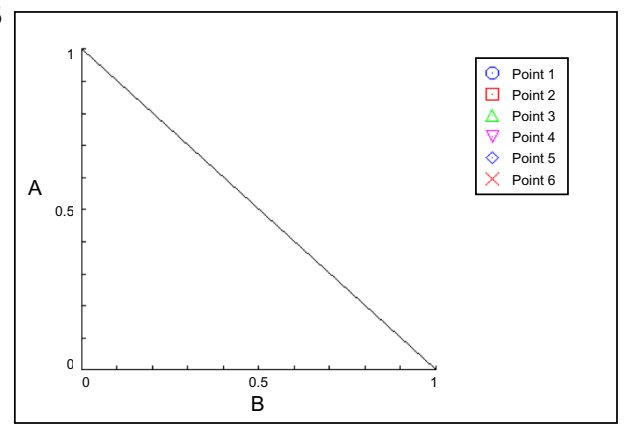

\begin{tabular}{|l|l|l|l|}
\hline $\begin{array}{c}\text { Dose NDV } \\
\text { PFUs }\end{array}$ & $\begin{array}{c}\text { Dose of Rtx } \\
\boldsymbol{\mu g} / \mathbf{m L}\end{array}$ & \multicolumn{1}{c|}{ Effect $\%$} & Cl \\
\hline $7,000.0$ & 2.5 & 0.9 & 103.246 \\
\hline $3,500.0$ & 1.25 & 0.13 & 71.6108 \\
\hline $1,750.0$ & 0.625 & 0.17 & 13.6456 \\
\hline 875.0 & 312.5 & 0.5 & 46.8482 \\
\hline 437.5 & 156.5 & 0.3 & 326.214 \\
\hline 218.7 & 78.25 & 0.12 & 5919.22 \\
\hline
\end{tabular}

Figure 4 Isobologram analysis.

Notes: (A) Synergism between NDV and Rtx at a low dose and antagonism effects at high dose on a CD20-positive plasmacytoma cell line. (B) The effect on rat embryonic cells was antagonistic at all doses used.

Abbreviations: NDV, Newcastle disease virus; Rtx, rituximab; PFUs, plaque-forming units; $\mathrm{Cl}$, combination index.

of $\mathrm{CD} 20^{+}$lymphocytes by three different mechanisms: complement-dependent cytotoxicity, antibody-dependent cytotoxicity and induction of apoptosis..$^{41}$ The first two mechanisms depend on the immune response, which was excluded from our in vitro work, but we can hypothesize that NDV will work well with these two mechanisms as it has immunostimulatory properties. ${ }^{9}$ The third mechanism, which is induction of apoptosis, can be orchestrated very well with NDV. Nevertheless, though the concentration of $\mathrm{p} 53$ measured at synergistic doses showed no significant $\mathrm{p} 53$ increase, we can still propose that the synergism between NDV and Rtx is apoptosis-induction synergism, as Rtx induces apoptosis through a signaling pathway
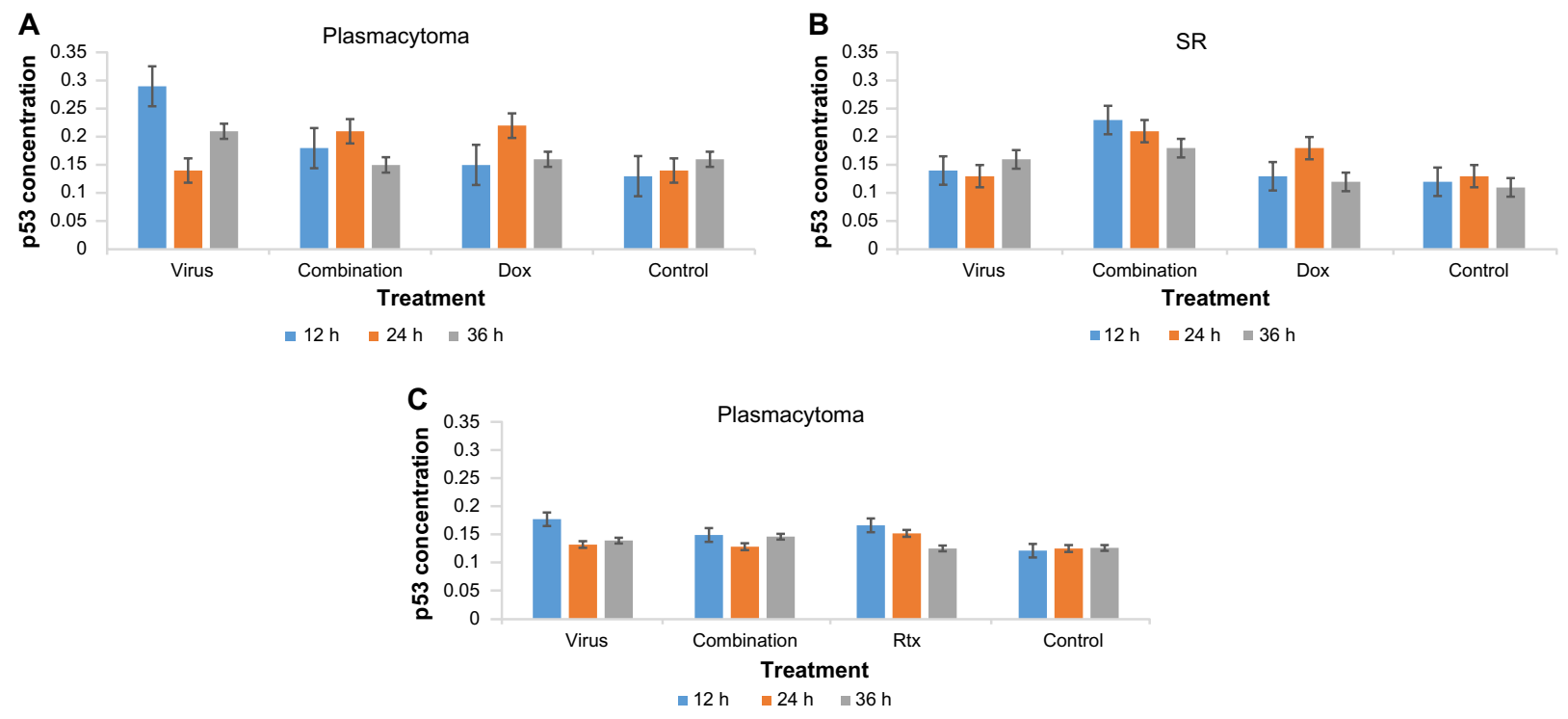

Figure 5 Concentration of the $\mathrm{p} 53$ protein in the treated cells with NDV, drug, and combination using synergistic doses.

Notes: (A) Plasmacytoma cell line treated with NDV and Dox, as well as their combination, showing no effect on p53 expression when compared to other treated groups, while NDV was the best for inducing the p53 protein at 12 and 36 hours. (B) Lymphoma cells treated with NDV, Dox, or their combination, which showed higher p53 induction at all time intervals tested. (C) Plasmacytoma cell line treated with NDV, Rtx, or their combination, showing no significant increase in p53 concentration. Abbreviations: NDV, Newcastle disease virus; Rtx, rituximab; Dox, doxorubicin. 
that is dependent on p38 MAP kinase activation when bound to CD20 on freshly isolated B-CLL cells, ${ }^{42}$ which means it is not p53-dependent. NDV, on the other hand, induces apoptosis very efficiently in a p53-independent manner, ${ }^{43}$ wherein the Iraqi NDV strain has been shown to induce apoptosis through an intrinsic pathway in vitro. ${ }^{11}$ The combination of ND virotherapy with Rtx was not synergistic on rat embryo fibroblast cells. NDV has been shown to be selective in replicating in tumor cells and not replicating on normal fibroblast cell lines. ${ }^{44}$ The combination of oncolytic RNA viruses with cytotoxic agents, such as signaling inhibitors or immunomodulators, has shown promise as a novel experimental method to overcome resistance to viral oncolysis. These agents complement oncolytic RNA virotherapy by unblocking host pathways, delivering viruses efficiently, and/or increasing virus replication inside cancer cells. ${ }^{45}$

In conclusion, NDV is a very promising anti-hematological malignancy agent when combined with other antitumor agents. It was found to be synergistic with Dox at low doses on plasmacytoma cells with no involvement of p53 pathways, but involved p53 when the combination was used on nonHodgkin lymphoma cells. When combined with Rtx, NDV showed enhanced cytotoxicity on plasmacytoma, which is p53-independent. These results indicate a novel combination that can enhance the anti-hematological malignancy ability for both oncolytic virotherapy and drugs.

\section{Acknowledgment}

This study was conducted in the Department of Experimental Therapeutics, Iraqi Center for Cancer and Medical Genetic Research, Mustansiriyah University, Baghdad, Iraq.

\section{Disclosure}

The authors report no conflicts of interest in this work.

\section{References}

1. Rodriguez-Abreu D, Bordoni A, Zucca E. Epidemiology of hematological malignancies. Ann Oncol. 2007;18 Suppl 1: i3-i8.

2. Tysome JR, Lemoine NR, Wang Y. Update on oncolytic viral therapy targeting angiogenesis. Onco Targets Ther. 2013;6:1031-1040.

3. Meerani S, Yao Y. Oncolytic viruses in cancer therapy. Eur J Sci Res. 2010;40(1):156-171.

4. Al-Shammari AM, Ismaeel FE, Salih SM, Yaseen N. Live attenuated measles virus vaccine therapy for locally established malignant glioblastoma tumor cells. Oncolytic Virother. 2014;3:57-68.

5. Schirrmacher V. Oncolytic Newcastle disease virus as a prospective anti-cancer therapy: a biologic agent with potential to break therapy resistance. Expert Opin Biol Ther. 2015;15(12):1757-1771.

6. Al-Shammari AM, Al-Nassrawei HA, Kadhim AM. Isolation and serodiagnosis of Newcastle disease virus infection in human and chicken poultry flocks in three cities of middle Euphrates. Kufa J Vet Med Sci. 2014;5(1):16-21.
7. Al-Shammari A, Yaseen N, Alwan M. Newcastle disease virus Iraqi local isolate as a therapy for murine mammary adenocarcinoma: in vitro and in vivo study. EJC Suppl. 2010;8(7):171.

8. Al-Shammari AM, Yaseen N, Alwan MJ. Immunology study for NDV treatment in mice bearing mammary adenocarcinoma tumor. Iraqi $J$ Cancer Med Genet. 2011;4(1):11-21.

9. Al-Shamery AM, Yaseen N, Alwan MJ. Study the antigenic modification of tumor cell surface by NDV infection. Iraqi $J$ Cancer. 2009;2(1):95-100.

10. Al-Shammari AM, Yaseen N, Alwan MJ. Newcastle disease virus Iraqi oncolytic strain induce [sic] apoptosis in tumor cells through endoplasmic reticulum pathway. Iraqi J Cancer Med Genet. 2012;5(1):34-41.

11. Al-Shammari AM, Humadi TJ, Al-Taee EH, Al-Atabi SM, Yaseen N. Oncolytic Newcastle disease virus Iraqi virulent strain induce [sic] apoptosis in vitro through intrinsic pathway and association of both intrinsic and extrinsic pathways in vivo. Mol Ther. 2015;23 Suppl 1:S173-S174.

12. Al-Shammary AM, Hassani HH, Ibrahim UA. Newcastle disease virus (NDV) Iraqi strain AD2141 induces DNA damage and FasL in cancer cell lines. J Biol Life Sci. 2014;5(1):1-11.

13. Chu RL, Post DE, Khuri FR, Van Meir EG. Use of replicating oncolytic adenoviruses in combination therapy for cancer. Clin Cancer Res. 2004;10(16):5299-5312.

14. Yardley DA. Drug Resistance and the Role of Combination Chemotherapy in Improving Patient Outcomes. International Journal of Breast Cancer. 2013;2013:1-15.

15. Al-Shammari AM, Lech PJ, Russell SJ. Photosensitizing oncolytic measles virus for cancer viro-photodynamic therapy. Mol Ther. 2014;22 Suppl 1:S65.

16. Al-Shammari AM, Yaseen N. In vitro synergistic enhancement of Newcastle disease virus to methotrexate cytotoxicity against tumor cells. Al-Anbar J Vet Sci. 2012;5(2):102-109.

17. Ottolino-Perry K, Diallo JS, Lichty BD, Bell JC, McCart JA. Intelligent design: combination therapy with oncolytic viruses. Mol Ther. 2010;18(2):251-263.

18. Avivi I, Robinson S, Goldstone A. Clinical use of rituximab in haematological malignancies. Br J Cancer. 2003;89(8):1389-1394.

19. Cerny T, Borisch B, Introna M, Johnson P, Rose AL. Mechanism of action of rituximab. Anticancer Drugs. 2002;13 Suppl 2:S3-S10.

20. Wilson WH, Gutierrez M, O'Connor P, et al. The role of rituximab and chemotherapy in aggressive B-cell lymphoma: a preliminary report of dose-adjusted EPOCH-R. Semin Oncol. 2002;29(1 Suppl 2):41-47.

21. Humphrey RW, Brockway-Lunardi LM, Bonk DT, et al. Opportunities and challenges in the development of experimental drug combinations for cancer. J Natl Cancer Inst. 2011;103(16):1222-1226.

22. Cutts SM, Nudelman A, Rephaeli A, Phillips DR. The power and potential of doxorubicin-DNA adducts. IUBMB Life. 2005;57(2):73-81.

23. Kumar S, Gao L, Yeagy B, Reid T. Virus combinations and chemotherapy for the treatment of human cancers. Curr Opin Mol Ther. 2008;10(4):371-379.

24. Al-Shammari AM, Yaseen N, Alwan MJ. Cyclophosphamide synergistically enhance Newcastle disease virus Iraqi strain oncolytic activity. Poster presented at: 6th International Conference on Oncolytic Viruses as Cancer Therapeutics; March 16-19, 2011; Las Vegas, NV.

25. Rivlin N, Brosh R, Oren M, Rotter V. Mutations in the p53 tumor suppressor gene: important milestones at the various steps of tumorigenesis. Genes Cancer. 2011;2(4):466-474.

26. Lane DP, Cheok CF, Lain S. P53-based cancer therapy. Cold Spring Harb Perspect Biol. 2010;2(9):a001222.

27. Saha MN, Qiu L, Chang H. Targeting p53 by small molecules in hematological malignancies. J Hematol Oncol. 2013;6:23.

28. Beckwith M, Longo DL, O'Connell CD, Moratz CM, Urba WJ. Phorbol ester-induced, cell-cycle-specific, growth inhibition of human B-lymphoma cell lines. J Natl Cancer Inst. 1990;82(6):501-509.

29. Al-Shammari AM, Yaseen N, Hussien A, Murad S, Ahmed AA. Induction of plasmacytoma in mice and establishment of continuous cell line that lack retinoblastoma gene expression. Iraqi J Cancer Med Genet. 2011;4(2):62-65. 
30. Chou TC. Drug combination studies and their synergy quantification using the Chou-Talalay method. Cancer Res. 2010;70(2):440-446.

31. Chou TC. Theoretical basis, experimental design, and computerized simulation of synergism and antagonism in drug combination studies. Pharmacol Rev. 2006;58(3):621-681.

32. Hiddemann W, Kneba M, Dreyling M, et al. Frontline therapy with rituximab added to the combination of cyclophosphamide, doxorubicin, vincristine, and prednisone (CHOP) significantly improves the outcome for patients with advanced-stage follicular lymphoma compared with therapy with $\mathrm{CHOP}$ alone: results of a prospective randomized study of the German Low-Grade Lymphoma Study Group. Blood. 2005; 106(12):3725-3732.

33. Sothern RB, Lévi F, Haus E, Halberg F, Hrushesky WJ. Control of a murine plasmacytoma with doxorubicin-cisplatin: dependence on circadian stage of treatment. J Natl Cancer Inst. 1989;81(2):135-145.

34. Russell SJ, Federspiel MJ, Peng KW, et al. Remission of disseminated cancer after systemic oncolytic virotherapy. Mayo Clin Proc. 2014;89(7):926-933.

35. Merin NM, Kelly KR. Clinical use of proteasome inhibitors in the treatment of multiple myeloma. Pharmaceuticals (Basel). 2014;8(1):1-20.

36. Gewirtz DA. A critical evaluation of the mechanisms of action proposed for the antitumor effects of the anthracycline antibiotics adriamycin and daunorubicin. Biochem Pharmacol. 1999;57(7):727-741.

37. Goebel SJ, Taylor J, Barr BC, et al. Isolation of avian paramyxovirus 1 from a patient with a lethal case of pneumonia. $J$ Virol. 2007;81(22):12709-12714.
38. Bar-Eli N, Giloh H, Schlesinger M, Zakay-Rones Z. Preferential cytotoxic effect of Newcastle disease virus on lymphoma cells. J Cancer Res Clin Oncol. 1996;122(7):409-415.

39. Allende-Vega N, Krzywinska E, Orecchioni S, et al. The presence of wild type p53 in hematological cancers improves the efficacy of combinational therapy targeting metabolism. Oncotarget. 2015;6(22):19228-19245.

40. Wang S, Konorev EA, Kotamraju S, Joseph J, Kalivendi S, Kalyanaraman B. Doxorubicin induces apoptosis in normal and tumor cells via distinctly different mechanisms: intermediacy of $\mathrm{H}_{2} \mathrm{O}_{2}$ - and $\mathrm{p} 53$-dependent pathways. J Biol Chem. 2004;279(24):25535-25543.

41. Pescovitz MD. Rituximab, an anti-CD20 monoclonal antibody: history and mechanism of action. Am J Transplant. 2006;6(5 Pt 1):859-866.

42. Pedersen IM, Buhl AM, Klausen P, Geisler CH, Jurlander J. The chimeric anti-CD20 antibody rituximab induces apoptosis in B-cell chronic lymphocytic leukemia cells through a p38 mitogen activated proteinkinase-dependent mechanism. Blood. 2002;99(4):1314-1319.

43. Fábián Z, Csatary CM, Szeberényi J, Csatary LK. P53-independent endoplasmic reticulum stress-mediated cytotoxicity of a Newcastle disease virus strain in tumor cell lines. J Virol. 2007;81(6):2817-2830.

44. Reichard KW, Lorence RM, Cascino CJ, et al. Newcastle disease virus selectively kills human tumor cells. J Surg Res. 1992;52(5):448-453.

45. Nguyen TL, Tumilasci VF, Singhroy D, Arguello M, Hiscott J. The emergence of combinatorial strategies in the development of RNA oncolytic virus therapies. Cell Microbiol. 2009;11(6):889-897.
Oncolytic Virotherapy

\section{Publish your work in this journal}

Oncolytic Virotherapy is an international, peer-reviewed, open access online journal publishing original research, study protocols, reviews, editorials and commentaries on all aspects of oncolytic virology, namely the application of oncolytic viruses for the treatment of cancer. Specific topics in the journal include: Rationale and theoretical aspects of oncolytic virotherapy including in vitro, in vivo and mathematical

Submit your manuscript here: http://www.dovepress.com/oncolytic-virotherapy-journal

\section{Dovepress}

modeling; and practical application and problem solving in the clinic including identification of potential responders through biomarkers and genetic profiling. The manuscript management system is completely online and includes a very quick and fair peer-review system, which is all easy to use. Visit http://www.dovepress.com/ testimonials.php to read real quotes from published authors. 